THE LOW-TEMPERATURE PARTIAL OXIDATION REFORMING OF FUELS

\author{
FOR TRANSPORTATION FUEL CELL SYSTEMS* \\ by

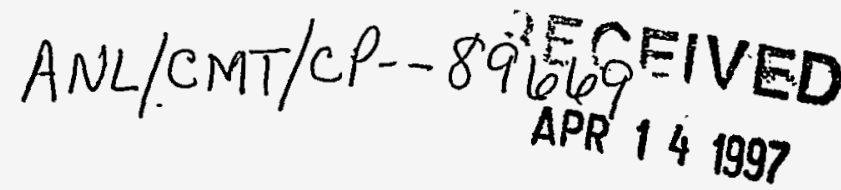 \\ R. Kumar, S. Ahmed, and M. Krumpelt \\ OSTI \\ Electrochemical Technology Program \\ Argonne National Laboratory \\ 9700 South Cass Avenue \\ Argonne, IL 60439
}

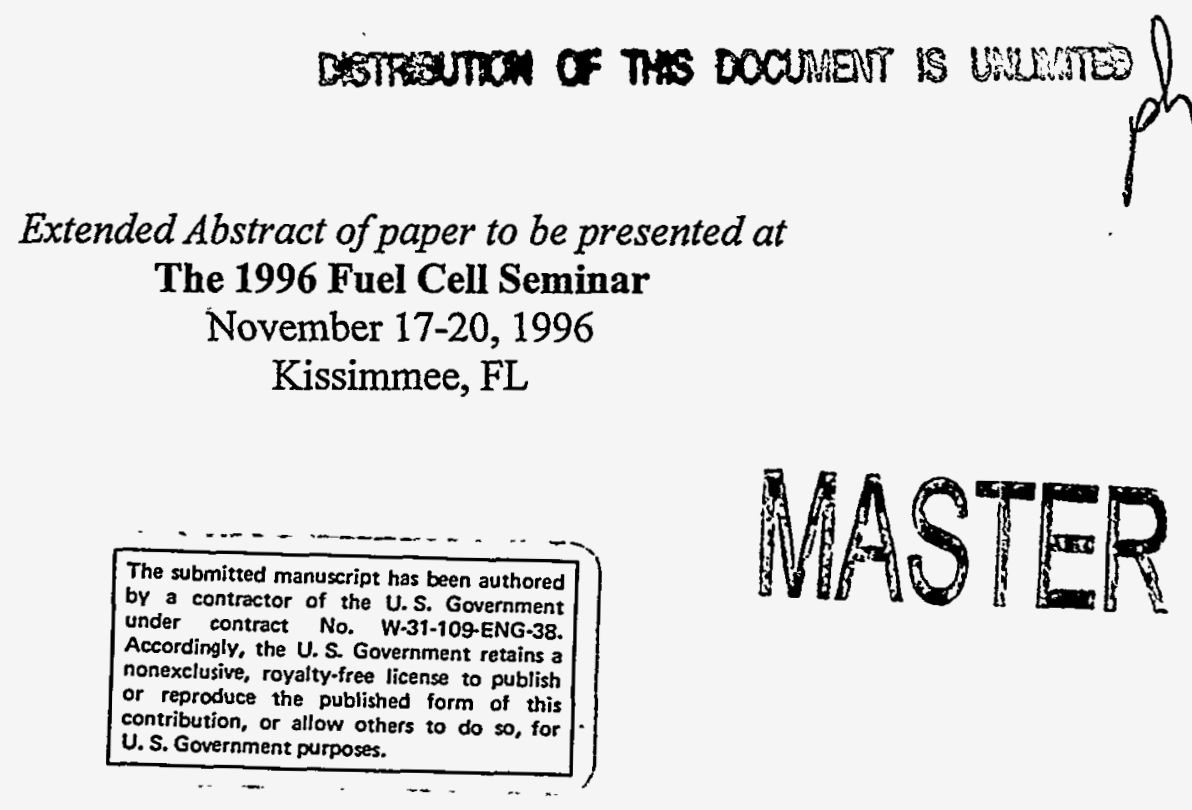

*This work was supported by the U.S. Department of Energy, Office of Advanced Automotive Technologies in the Office of Transportation Technologies, under contract number W-31-109ENG-38. 


\section{DISCLAIMIER}

Portions of this document may be illegible in electronic image products. Images are produced from the best available original document. 


\section{DISCLAIMER}

This report was prepared as an account of work sponsored by an agency of the United States Government. Neither the United States Government nor any agency thereof, nor any of their employees, make any warranty, express or implied, or assumes any legal liability or responsibility for the accuracy, completeness, or usefulness of any information, apparatus, product, or process disclosed, or represents that its use would not infringe privately owned rights. Reference herein to any specific commercial product, process, or service by trade name, trademark, manufacturer, or otherwise does not necessarily constitute or imply its endorsement, recommendation, or favoring by the United States Government or any agency thereof. The views and opinions of authors expressed herein do not necessarily state or reflect those of the United States Government or any agency thereof. 


\title{
THE LOW-TEMPERATURE PARTIAL-OXIDATION REFORMING OF FUELS FOR TRANSPORTATION FUEL CELL SYSTEMS
}

\author{
R. Kumar, S. Ahmed, and M. Krumpelt \\ Electrochemical Technology Program \\ Chemical Technology Division \\ Argonne National Laboratory \\ Argonne, IL 60439
}

\section{Introduction}

Passenger cars powered by fuel cell propulsion systems with high efficiency offer superior fuel economy, very low to zero pollutant emissions, and the option to operate on alternative and/or renewable fuels. Although the fuel cell operates on hydrogen, a liquid fuel such as methanol or gasoline is more attractive for automotive use because of the convenience in handling and vehicle refueling. Such a liquid fuel must be dynamically converted (reformed) to hydrogen on board the vehicle in real time to meet fluctuating power demands [1]. This paper describes the lowtemperature Argonne partial-oxidation reformer (APOR) developed for this application. The APOR is a rapid-start, compact, lightweight, catalytic device that is efficient and dynamically responsive. The reformer is easily controlled by varying the feed rates of the fuel, water, and air to satisfy the rapidly changing system power demands during the vehicle's driving cycle.

\section{Reforming Processes}

Hydrogen may be produced from fuels by either steam reforming or partial-oxidation reforming. In a steam reformer, the fuel (hydrocarbon, alcohol, etc.) is reacted with steam over a catalyst at a high temperature and pressure. The reaction is endothermic, and the heat of reaction is provided by the combustion of fuel and transferred to the process gas across a metal wall. Because of the indirect heat transfer, steam reformers are heavy, bulky, slow to start, and slow to respond to load changes. In a partial-oxidation reformer, part of the fuel is oxidized to provide the energy for the reforming reaction within the process gas. The direct heat transfer makes such a reformer compact, lightweight, and dynamically responsive. The addition of a suitable catalyst can be used to influence the product gas composition. The steam reformer is relatively complex, since it contains burners, extended heat transfer surfaces, and combustion air and exhaust duct work. The partial-oxidation reformer is mechanically simple due to the absence of these components.

\section{Fuel Cell Systems}

Figure 1 shows greatly simplified schematic diagrams for two fuel cell systems, one with a steam reformer and one with an APOR [2]. In the system with a steam reformer, the fuel and water are fed to the reformer, the temperature, humidity, and contaminant levels in the reformate are adjusted (not shown), and the fuel gas is then fed to the fuel cell stack, where $80-85 \%$ of the hydrogen is electrochemically oxidized to generate electricity. The exhaust fuel gas is recycled to the burner to provide the energy for fuel reforming. In the system with the APOR, the fuel, water, and air are fed to the reformer, and the reformate (after appropriate conditioning) is fed to the fuel cell stack; the spent fuel gas is not recycled to the reformer, although a catalytic burner (not shown) is used to avoid venting hydrogen to the environment.

The dynamic response of a steam-reformed, methanol-fueled, polymer electrolyte fuel cell system has been analyzed [3]. Different turn-down scenarios (from steady-state at the design point) were analyzed. In one, the flow rates of the fuel gas and air were ramped down while maintaining fuel utilization $\left(u_{f}\right)$ constant at $85 \%$. For a $50 \%$ reduction in power level, the simulation showed that the reformer catalyst overheated within a few seconds. One solution to alleviating this problem is to inject additional water into the process gas just ahead of the reformer. However, if the fuel gas flow rate is not decreased in concert with the decrease in fuel cell power, combustion of the excess hydrogen in the spent fuel gas at the reformer burner rapidly leads to unacceptably high reformer catalyst temperatures. These scenarios are discussed in detail in reference [3]. 
The dynamic response of the APOR is excellent. Power transients are accommodated simply by varying the feed rates of fuel, water, and air to the APOR. The product gas flow rate responds almost instantaneously, while its composition remains essentially constant. The reactor temperatures (and, therefore, the reaction chemistries and kinetics) are not significantly affected by changes in the fuel processing rate. Thus, the process control for the APOR is analogous to that of the fuel injection systems used in today's cars.

The calculated steady-state efficiencies of the two systems (fueled with methanol) are shown in Fig. 2. At a $u_{f}$ of $85 \%$ or greater, the efficiency of the system with the APOR exceeds that of the steam reformer system. In automotive applications, the APOR system will be more efficient even at a lower $u_{f}$ because the efficiency of the steam-reformer system decreases under fluctuating power demands [1]. The efficiency of the fuel cell system with the APOR is largely unaffected by power transients.

\section{Argonne's Partial-Oxidation Reformer for Methanol}

In the methanol APOR, hydrogen is generated by a combination of the exothermic partial-oxidation reaction, the endothermic decomposition and steam-reforming reactions, and the water-gas shift reaction:

$$
\begin{aligned}
\mathrm{CH}_{3} \mathrm{OH}(\ell)+1 / 2 \mathrm{O}_{2} & \rightarrow 2 \mathrm{H}_{2}+\mathrm{CO}_{2} & \Delta \mathrm{H}_{298}=-155 \mathrm{~kJ} \\
\mathrm{CH}_{3} \mathrm{OH}(\ell) & \rightarrow 2 \mathrm{H}_{2}+\mathrm{CO} & \Delta \mathrm{H}_{298}=+128 \mathrm{~kJ} \\
\mathrm{CH}_{3} \mathrm{OH}(\ell)+\mathrm{H}_{2} \mathrm{O}(\ell) & \rightarrow 3 \mathrm{H}_{2}+\mathrm{CO}_{2} & \Delta \mathrm{H}_{298}=+131 \mathrm{~kJ} \\
\mathrm{CO}+\mathrm{H}_{2} \mathrm{O}(\ell) & \rightarrow \mathrm{H}_{2}+\mathrm{CO}_{2} & \Delta \mathrm{H}_{298}=+3 \mathrm{~kJ}
\end{aligned}
$$

The overall methanol-reforming reaction in the APOR may be written as:

$$
\mathrm{CH}_{3} \mathrm{OH}+x\left(\mathrm{O}_{2}+3.76 \mathrm{~N}_{2}\right)+(1-2 x) \mathrm{H}_{2} \mathrm{O} \rightarrow(3-2 x) \mathrm{H}_{2}+\mathrm{CO}_{2}+3.76 x \mathrm{~N}_{2}
$$

where $x$ is the oxygen-to-methanol molar ratio, and $(1-2 x)$ is the theoretical amount of water required to completely convert $\mathrm{CO}$ to $\mathrm{CO}_{2}$. The energy released (or absorbed) by reaction (5) depends on the value of $x$. At $x=0$, reaction (5) becomes the endothermic steam-reforming reaction (3); at $x=0.5$, reaction (5) becomes the exothermic partial-oxidation reaction (1). Reaction $(5)$ becomes thermally neutral at $x \approx 0.23$. To provide for the sensible heat in the reformate and the heat loss from the reactor, the operating oxygen-to-methanol ratio is a little higher than that needed for thermal neutrality.

The bench-scale APOR built and tested in our laboratory is shown schematically in Fig. 3 [4]. It consists of a cylindrical reactor packed with a copper-zinc oxide catalyst (both pellet and honeycomb catalyst structures have been tested). Methanol and water are injected as a fine spray (by using an ultrasonic nozzle) into a down-flowing air stream. The fuel-water-air mixture flows past a nichrome wire "igniter," which vaporizes a small amount of the methanol. The methanol is oxidized on the surface of the catalyst, and the heat generated rapidly raises the temperature near the inlet end of the catalyst bed to $\approx 500^{\circ} \mathrm{C}$; methanol decomposition, steam-reforming, and the water-gas shift reactions then decrease the temperature to $\approx 200^{\circ} \mathrm{C}$ at the reactor exit. The reformate contains $\sim 50 \% \mathrm{H}_{2}, \sim 1 \% \mathrm{CO}$, and no $\mathrm{CH}_{4}$ (see Fig. 4). The APOR needs no external heating or cooling. The reformate from the APOR can be fed to a phosphoric acid fuel cell as is, but it must be conditioned (e.g., preferential oxidation to reduce $\mathrm{CO}$ plus water injection to cool and humidify) before being fed to a polymer electrolyte fuel cell.

\section{Discussion}

A big advantage of the APOR over the more conventional steam reformer arises from the absence of indirect heat transfer, thus avoiding the weight and volume of the heat exchange components in a steam reformer. For example, the weight and volume of the methanol steam 
reformer in the transit bus powered by a $50-\mathrm{kW}$ phosphoric acid fuel cell are $266 \mathrm{~kg}$ and $415 \mathrm{~L}$, respectively [5]; the corresponding values for the APOR are less than $35 \mathrm{~kg}$ and $25 \mathrm{~L}$.

Because the mass (and the corresponding thermal mass) of the APOR is lower than that of the steam reformer, the time and fuel consumed during reformer start-up are reduced by at least one order of magnitude. Figure 5 shows that in the APOR, significant hydrogen is produced in less than two minutes; the steam reformer on the fuel cell bus requires at least 30 minutes.

The reformate from the APOR does have a lower $\mathrm{H}_{2}$ concentration than that from a steam reformer (50\% rather than $70-75 \%)$, leading to a small decrease $(-10 \mathrm{mV})$ in cell voltage. Another disadvantage of the APOR is that the fuel cell anode must accommodate a 50\% greater flow rate, requiring wider flow passages and leading to a decreased power density of the fuel cell stack. The reduced power density is offset, however, by the comparative simplicity of the fuel cell system using the APOR instead of a steam reformer. Simplifications include elimination of the recycle loop and the reformer burner, as well as the air and fuel preheater and/or vaporizer.

The APOR uses the copper-zinc oxide catalyst in the oxidized form, which does not sinter easily and can withstand high temperatures without degradation. The catalyst needs no activation before use, nor sequestration between uses, and may routinely be heated to $500^{\circ} \mathrm{C}$ or greater. The steam reformer uses a similar catalyst, but in a reduced form; the catalyst must be kept isolated from air, which would reoxidize it and render it ineffective. Also, the reduced catalyst sinters readily, and temperatures above $-280^{\circ} \mathrm{C}$ must be avoided.

\section{Hydrocarbon Reforming}

There is a great deal of interest in operating fuel cell vehicles on conventional gasoline and diesel fuels. The APOR concept has been used to reform the simple hydrocarbons octane and pentane as surrogates for such fuels. Preliminary tests with selected catalysts have yielded $\mathrm{H}_{2}$ concentrations $>40 \%$. Research to develop improved catalysts is continuing.

\section{Conclusion}

Argonne's partial-oxidation reformer is a compact, lightweight, rapid-start, and dynamically responsive device to convert liquid fuels to $\mathrm{H}_{2}$ for use in automotive fuel cells. An APOR catalyst for methanol has been developed and tested; catalysts for other fuels are being evaluated. Simple in design, operation, and control, the APOR can help develop efficient fuel cell propulsion systems.

\section{Acknowledgment}

This research was supported by the U.S. Department of Energy, Office of Advanced Automotive Technologies in the Office of Transportation Technologies, under contract number W-31-109-Eng-38.

\section{References}

1. "Reformers for the Production of Hydrogen from Methanol and Alternative Fuels for Fuel Cell Powered Vehicles," R. Kumar, S. Ahmed, M. Krumpelt, and K. M. Myles, Argonne National Laboratory Report ANL-92/31, 1992.

2. "Fundamentals of Fuel Cell System Integration," M. Krumpelt, R. Kumar, and K. M. Myles, Journal of Power Sources, 49, 37-51 (1994).

3. "Dynamic Response of Steam-Reformed, Methanol-Fueled, Polymer Electrolyte Fuel Cell Systems," H. K. Geyer, R. K. Ahluwalia, and R. Kumar, Proceedings of the 31st Intersociety Energy Conversion Engineering Conference IECEC 96, August 11-16, 1996, Washington, DC, Vol. 2, pp. 1101-1106.

4. "Fuels Processing for Transportation Fuel Cell Systems," R. Kumar and S. Ahmed, Proceedings of the First International Symposium on New Materials for Fuel Cell Systems, July 9-13, 1995, Montreal, Canada, pp. 224-238.

5. "Research and Development of a Phosphoric Acid Fuel Cell/Battery Power Source Integrated in A Test-Bed Bus," Phase II Final Report HPC-0144, H-Power Corp., Belleville, NJ, May 30, 1996, p. 24. 


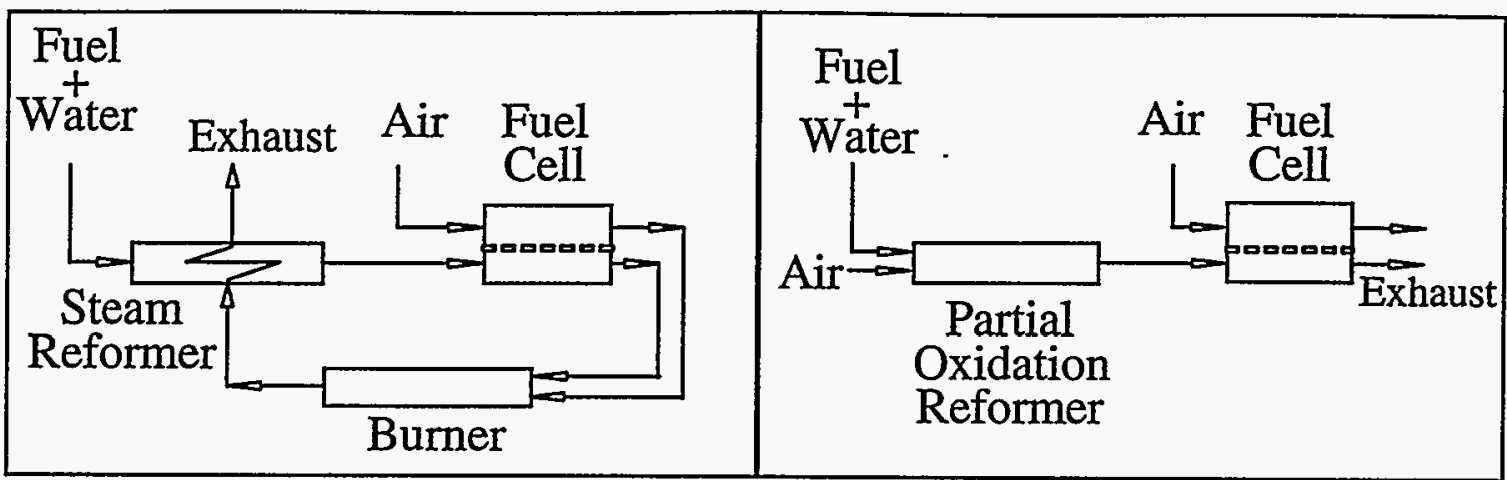

(a)

(b)

Fig. 1. Simplified schematics for fuel cell systems with (a) steam reformer, and (b) partial-oxidation reformer to convert liquid fuel to hydrogen for use in the fuel cell stack.

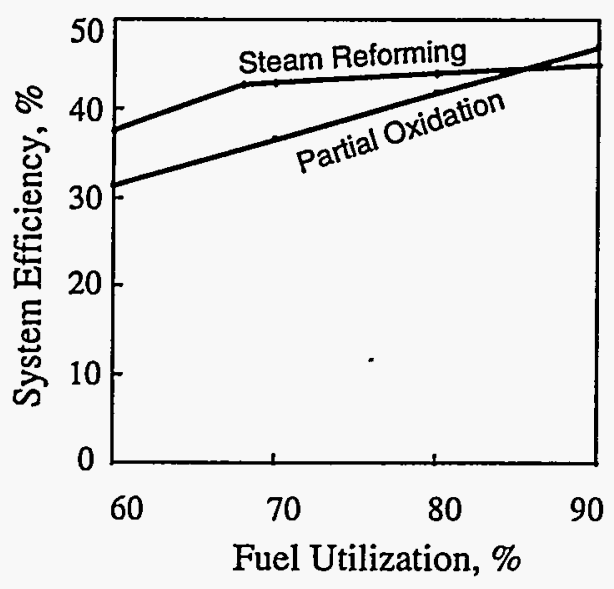

Fig. 2. Effect of fuel utilization on efficiencies of the two systems shown in Fig. 1.

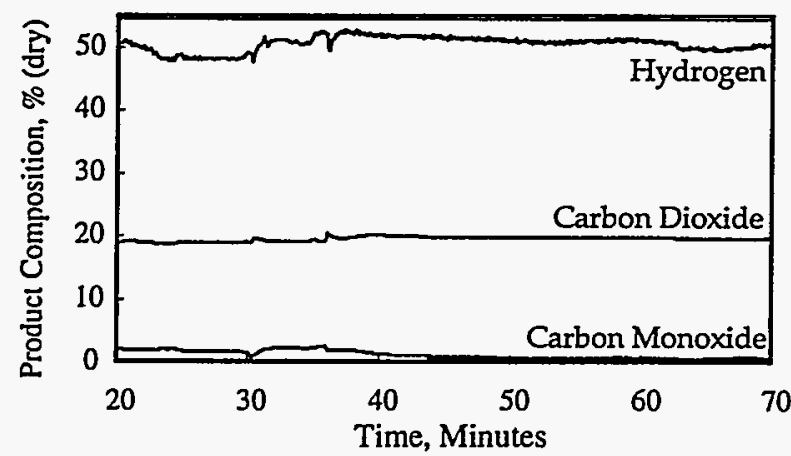

Fig. 4. Typical reformate composition from the APOR.

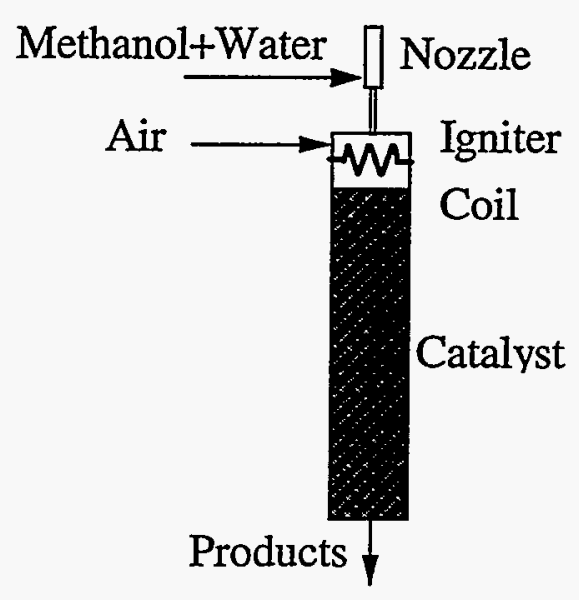

Fig. 3. Schematic of the APOR.

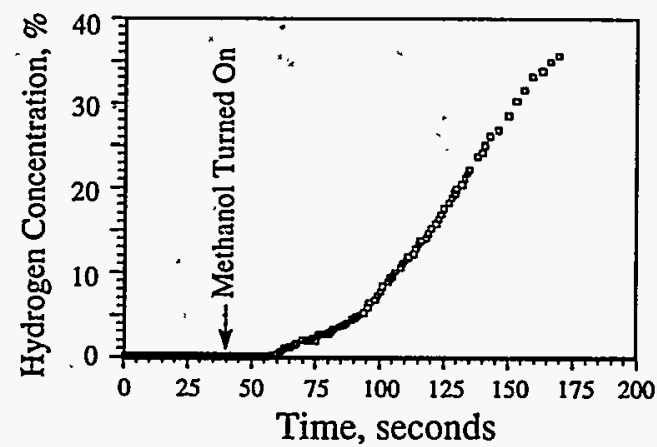

Fig. 5. Hydrogen production from the APOR during cold-start. 
THE LOW-TEMPERATURE PARTIAL OXIDATION REFORMING OF FUELS

FOR TRANSPORTATION FUEL CELL SYSTEMS*

$$
\begin{array}{r}
\text { ANL/CMT/CP- } 8966 \text { GEIVED } \\
\text { APR } 141997 \\
\text { OSTI }
\end{array}
$$

R. Kumar, S. Ahmed, and M. Krumpelt

Electrochemical Technology Program

Argonne National Laboratory

9700 South Cass Avenue

Argonne, IL 60439

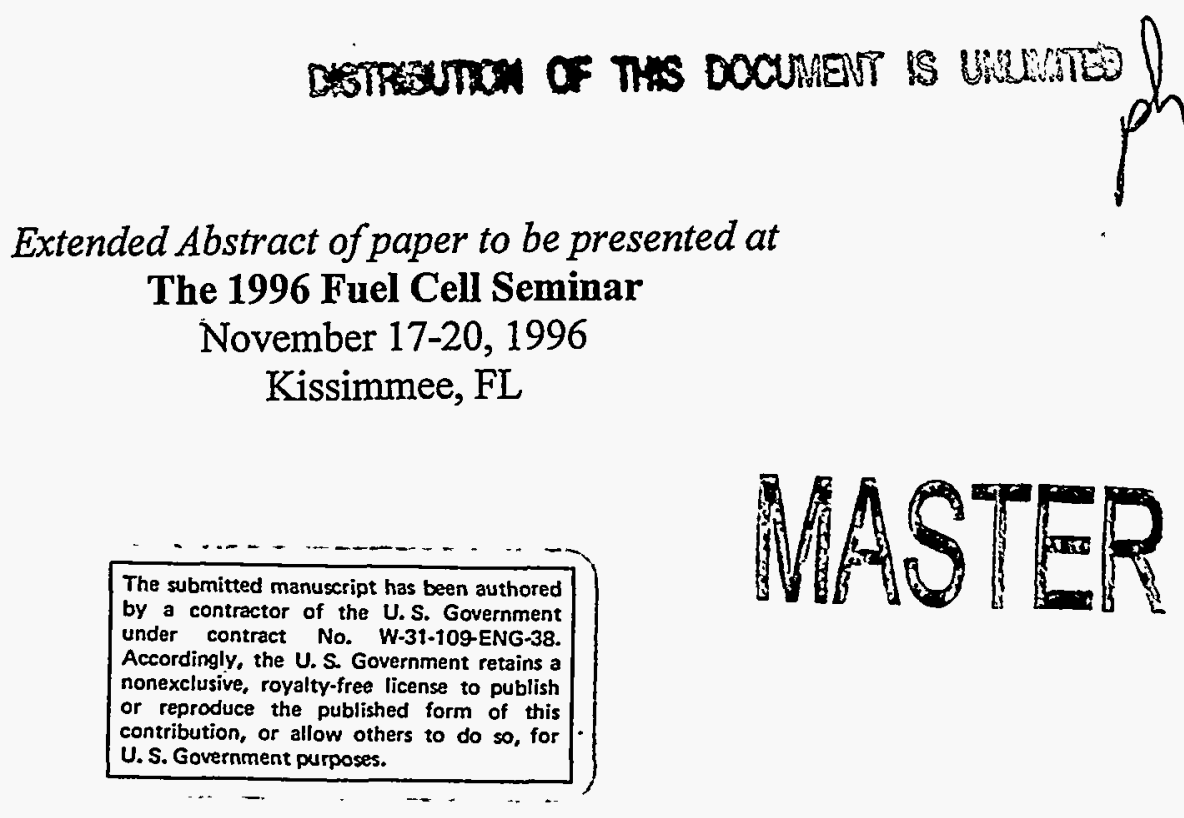

*This work was supported by the U.S. Department of Energy, Office of Advanced Automotive Technologies in the Office of Transportation Technologies, under contract number W-31-109ENG-38. 


\section{DISCLAIMER}

Portions of this document may be illegible in electronic image products. Images are produced from the best available original document. 


\section{DISCLAIMER}

This report was prepared as an account of work sponsored by an agency of the United States Government. Neither the United States Government nor any agency thereof, nor any of their employees, make any warranty, express or implied, or assumes any legal liability or responsibility for the accuracy, completeness, or usefulness of any information, apparatus, product, or process disclosed, or represents that its use would not infringe privately owned rights. Reference herein to any specific commercial product, process, or service by trade name, trademark, manufacturer, or otherwise does not necessarily constitute or imply its endorsement, recommendation, or favoring by the United States Government or any agency thereof. The views and opinions of authors expressed herein do not necessarily state or reflect those of the United States Government or any agency thereof. 


\author{
R. Kumar, S. Ahmed, and M. Krumpelt \\ Electrochemical Technology Program \\ Chemical Technology Division \\ Argonne National Laboratory \\ Argonne, IL 60439
}

\title{
Introduction
}

Passenger cars powered by fuel cell propulsion systems with high efficiency offer superior fuel economy, very low to zero pollutant emissions, and the option to operate on alternative and/or renewable fuels. Although the fuel cell operates on hydrogen, a liquid fuel such as methanol or gasoline is more attractive for automotive use because of the convenience in handling and vehicle refueling. Such a liquid fuel must be dynamically converted (reformed) to hydrogen on board the vehicle in real time to meet fluctuating power demands [1]. This paper describes the lowtemperature Argonne partial-oxidation reformer (APOR) developed for this application. The APOR is a rapid-start, compact, lightweight, catalytic device that is efficient and dynamically responsive. The reformer is easily controlled by varying the feed rates of the fuel, water, and air to satisfy the rapidly changing system power demands during the vehicle's driving cycle.

\section{Reforming Processes}

Hydrogen may be produced from fuels by either steam reforming or partial-oxidation reforming. In a steam reformer, the fuel (hydrocarbon, alcohol, etc.) is reacted with steam over a catalyst at a high temperature and pressure. The reaction is endothermic, and the heat of reaction is provided by the combustion of fuel and transferred to the process gas across a metal wall. Because of the indirect heat transfer, steam reformers are heavy, bulky, slow to start, and slow to respond to load changes. In a partial-oxidation reformer, part of the fuel is oxidized to provide the energy for the reforming reaction within the process gas. The direct heat transfer makes such a reformer compact, lightweight, and dynamically responsive. The addition of a suitable catalyst can be used to influence the product gas composition. The steam reformer is relatively complex, since it contains burners, extended heat transfer surfaces, and combustion air and exhaust duct work. The partial-oxidation reformer is mechanically simple due to the absence of these components.

\section{Fuel Cell Systems}

Figure 1 shows greatly simplified schematic diagrams for two fuel cell systems, one with a steam reformer and one with an APOR [2]. In the system with a steam reformer, the fuel and water are fed to the reformer, the temperature, humidity, and contaminant levels in the reformate are adjusted (not shown), and the fuel gas is then fed to the fuel cell stack, where $80-85 \%$ of the hydrogen is electrochemically oxidized to generate electricity. The exhaust fuel gas is recycled to the burner to provide the energy for fuel reforming. In the system with the APOR, the fuel, water, and air are fed to the reformer, and the reformate (after appropriate conditioning) is fed to the fuel cell stack; the spent fuel gas is not recycled to the reformer, although a catalytic burner (not shown) is used to avoid venting hydrogen to the environment.

The dynamic response of a steam-reformed, methanol-fueled, polymer electrolyte fuel cell system has been analyzed [3]. Different turn-down scenarios (from steady-state at the design point) were analyzed. In one, the flow rates of the fuel gas and air were ramped down while maintaining fuel utilization $\left(u_{f}\right)$ constant at $85 \%$. For a $50 \%$ reduction in power level, the simulation showed that the reformer catalyst overheated within a few seconds. One solution to alleviating this problem is to inject additional water into the process gas just ahead of the reformer. However, if the fuel gas flow rate is not decreased in concert with the decrease in fuel cell power, combustion of the excess hydrogen in the spent fuel gas at the reformer burner rapidly leads to unacceptably high reformer catalyst temperatures. These scenarios are discussed in detail in reference [3]. 
The dynamic response of the APOR is excellent. Power transients are accommodated simply by varying the feed rates of fuel, water, and air to the APOR. The product gas flow rate responds almost instantaneously, while its composition remains essentially constant. The reactor temperatures (and, therefore, the reaction chemistries and kinetics) are not significantly affected by changes in the fuel processing rate. Thus, the process control for the APOR is analogous to that of the fuel injection systems used in today's cars.

The calculated steady-state efficiencies of the two systems (fueled with methanol) are shown in Fig. 2. At a $u_{f}$ of $85 \%$ or greater, the efficiency of the system with the APOR exceeds that of the steam reformer system. In automotive applications, the APOR system will be more efficient even at a lower $u_{f}$ because the efficiency of the steam-reformer system decreases under fluctuating power demands [1]. The efficiency of the fuel cell system with the APOR is largely unaffected by power transients.

Argonne's Partial-Oxidation Reformer for Methanol

In the methanol APOR, hydrogen is generated by a combination of the exothermic partial-oxidation reaction, the endothermic decomposition and steam-reforming reactions, and the water-gas shift reaction:

$$
\begin{aligned}
\mathrm{CH}_{3} \mathrm{OH}(\ell)+1 / 2 \mathrm{O}_{2} & \rightarrow 2 \mathrm{H}_{2}+\mathrm{CO}_{2} & \Delta \mathrm{H}_{298}=-155 \mathrm{~kJ} \\
\mathrm{CH}_{3} \mathrm{OH}(\ell) & \rightarrow 2 \mathrm{H}_{2}+\mathrm{CO} & \Delta \mathrm{H}_{298}=+128 \mathrm{~kJ} \\
\mathrm{CH}_{3} \mathrm{OH}(\ell)+\mathrm{H}_{2} \mathrm{O}(\ell) & \rightarrow 3 \mathrm{H}_{2}+\mathrm{CO}_{2} & \Delta \mathrm{H}_{298}=+131 \mathrm{~kJ} \\
\mathrm{CO}+\mathrm{H}_{2} \mathrm{O}(\ell) & \rightarrow \mathrm{H}_{2}+\mathrm{CO}_{2} & \Delta \mathrm{H}_{298}=+3 \mathrm{~kJ}
\end{aligned}
$$

The overall methanol-reforming reaction in the APOR may be written as:

$$
\mathrm{CH}_{3} \mathrm{OH}+x\left(\mathrm{O}_{2}+3.76 \mathrm{~N}_{2}\right)+(1-2 x) \mathrm{H}_{2} \mathrm{O} \rightarrow(3-2 x) \mathrm{H}_{2}+\mathrm{CO}_{2}+3.76 x \mathrm{~N}_{2}
$$

where $x$ is the oxygen-to-methanol molar ratio, and $(1-2 x)$ is the theoretical amount of water required to completely convert $\mathrm{CO}$ to $\mathrm{CO}_{2}$. The energy released (or absorbed) by reaction (5) depends on the value of $x$. At $x=0$, reaction (5) becomes the endothermic steam-reforming reaction (3); at $x=0.5$, reaction (5) becomes the exothermic partial-oxidation reaction (1). Reaction (5) becomes thermally neutral at $x \approx 0.23$. To provide for the sensible heat in the reformate and the heat loss from the reactor, the operating oxygen-to-methanol ratio is a little higher than that needed for thermal neutrality.

The bench-scale APOR built and tested in our laboratory is shown schematically in Fig. 3 [4]. It consists of a cylindrical reactor packed with a copper-zinc oxide catalyst (both pellet and honeycomb catalyst structures have been tested). Methanol and water are injected as a fine spray (by using an ultrasonic nozzle) into a down-flowing air stream. The fuel-water-air mixture flows past a nichrome wire "igniter," which vaporizes a small amount of the methanol. The methanol is oxidized on the surface of the catalyst, and the heat generated rapidly raises the temperature near the inlet end of the catalyst bed to $=500^{\circ} \mathrm{C}$; methanol decomposition, steam-reforming, and the water-gas shift reactions then decrease the temperature to $\approx 200^{\circ} \mathrm{C}$ at the reactor exit. The reformate contains $\sim 50 \% \mathrm{H}_{2}, \sim 1 \% \mathrm{CO}$, and no $\mathrm{CH}_{4}$ (see Fig. 4). The APOR needs no external heating or cooling. The reformate from the APOR can be fed to a phosphoric acid fuel cell as is, but it must be conditioned (e.g., preferential oxidation to reduce $\mathrm{CO}$ plus water injection to cool and humidify) before being fed to a polymer electrolyte fuel cell.

\section{Discussion}

A big advantage of the APOR over the more conventional steam reformer arises from the absence of indirect heat transfer, thus avoiding the weight and volume of the heat exchange components in a steam reformer. For example, the weight and volume of the methanol steam 


\section{KUMAR ET AL}

reformer in the transit bus powered by a $50-\mathrm{kW}$ phosphoric acid fuel cell are $266 \mathrm{~kg}$ and $415 \mathrm{~L}$, respectively [5]; the corresponding values for the APOR are less than $35 \mathrm{~kg}$ and $25 \mathrm{~L}$.

Because the mass (and the corresponding thermal mass) of the APOR is lower than that of the steam reformer, the time and fuel consumed during reformer start-up are reduced by at least one order of magnitude. Figure 5 shows that in the APOR, significant hydrogen is produced in less than two minutes; the steam reformer on the fuel cell bus requires at least 30 minutes.

The reformate from the APOR does have a lower $\mathrm{H}_{2}$ concentration than that from a steam reformer (50\% rather than $70-75 \%)$, leading to a small decrease $(-10 \mathrm{mV})$ in cell voltage. Another disadvantage of the APOR is that the fuel cell anode must accommodate a $50 \%$ greater flow rate, requiring wider flow passages and leading to a decreased power density of the fuel cell stack. The reduced power density is offset, however, by the comparative simplicity of the fuel cell system using the APOR instead of a steam reformer. Simplifications include elimination of the recycle loop and the reformer burner, as well as the air and fuel preheater and/or vaporizer.

The APOR uses the copper-zinc oxide catalyst in the oxidized form, which does not sinter easily and can withstand high temperatures without degradation. The catalyst needs no activation before use, nor sequestration between uses, and may routinely be heated to $500^{\circ} \mathrm{C}$ or greater. The steam reformer uses a similar catalyst, but in a reduced form; the catalyst must be kept isolated from air, which would reoxidize it and render it ineffective. Also, the reduced catalyst sinters readily, and temperatures above $-280^{\circ} \mathrm{C}$ must be avoided.

\section{Hydrocarbon Reforming}

There is a great deal of interest in operating fuel cell vehicles on conventional gasoline and diesel fuels. The APOR concept has been used to reform the simple hydrocarbons octane and pentane as surrogates for such fuels. Preliminary tests with selected catalysts have yielded $\mathrm{H}_{2}$ concentrations $>40 \%$. Research to develop improved catalysts is continuing.

\section{Conclusion}

Argonne's partial-oxidation reformer is a compact, lightweight, rapid-start, and dynamically responsive device to convert liquid fuels to $\mathrm{H}_{2}$ for use in automotive fuel cells. An APOR catalyst for methanol has been developed and tested; catalysts for other fuels are being evaluated. Simple in design, operation, and control, the APOR can help develop efficient fuel cell propulsion systems.

\section{Acknowledgment}

This research was supported by the U.S. Department of Energy, Office of Advanced Automotive Technologies in the Office of Transportation Technologies, under contract number W-31-109-Eng-38.

\section{References}

1. "Reformers for the Production of Hydrogen from Methanol and Alternative Fuels for Fuel Cell Powered Vehicles," R. Kumar, S. Ahmed, M. Krumpelt, and K. M. Myles, Argonne National Laboratory Report ANL-92/31, 1992.

2. "Fundamentals of Fuel Cell System Integration," M. Krumpelt, R. Kumar, and K. M. Myles, Journal of Power Sources, 49, 37-51 (1994).

3. "Dynamic Response of Steam-Reformed, Methanol-Fueled, Polymer Electrolyte Fuel Cell Systems," H. K. Geyer, R. K. Ahluwalia, and R. Kumar, Proceedings of the 31st Intersociety Energy Conversion Engineering Conference IECEC 96, August 11-16, 1996, Washington, DC, Vol. 2, pp. 1101-1106.

4. "Fuels Processing for Transportation Fuel Cell Systems," R. Kumar and S. Ahmed, Proceedings of the First International Symposium on New Materials for Fuel Cell Systems, July 9-13, 1995, Montreal, Canada, pp. 224-238.

5. "Research and Development of a Phosphoric Acid Fuel Cell/Battery Power Source Integrated in A Test-Bed Bus," Phase II Final Report HPC-0144, H-Power Corp., Belleville, NJ, May 30, 1996, p. 24. 